\title{
Litigation Cost, Market-to-Book, and Asymmetric Timeliness of Earnings
}

\author{
Zhefeng Frank Liu (Corresponding author) \\ Assistant Professor, Goodman School of Business, Brock University \\ 500 Glenridge Avenue, St Catharines, Ontario L2S 3A1 Canada \\ Tel: 1-905-688-5550 ext 5834 E-mail: zliu@brocku.ca \\ Daniel B. Thornton \\ School of Business, Queen's University \\ 143 Union St., Kingston, Ontario K7L 3N6, Canada \\ Tel: 1-613-533-6194 E-mail: dbt@queensu.ca \\ Fayez A. Elayan \\ Goodman School of Business, Brock University \\ 500 Glenridge Avenue, St Catharines, Ontario L2S 3A1 Canada \\ Tel: 1-905-688-5550 ext 4160 E-mail: felayan@brocku.ca
}

Received: 22-02- 2013

Accepted: 15-03- 2013

Published: 30-04- 2013

doi:10.7575/aiac.ijfas.v.1n.1p.1

URL: http://dx.doi.org/10.7575/aiac.ijfas.v.1n.1p.1

The authors gratefully acknowledge comments from the editor, anonymous referees, discussants, and participants at the 2012 AAA annual conference, 2012 ASAC conference, Luo He at Concordia University and Michael Welker at Queen's University, and feedback from seminar participants at HEC Montréal and Queen's University. They gratefully acknowledge financial support from Institute for International Issues in Accounting (IIIA) at Brock University and the Social Sciences and Humanities Research Council of Canada (Grant No. 410-07-0352), the Chartered Accountants of Ontario Professorship, and Queen's School of Business. This paper won the Best Paper Award at the 2012 ASAC conference in St. John's, NL, Canada.

\begin{abstract}
Recent studies have questioned the validity of the Basu asymmetric timeliness of earnings (AT) as the proxy for accounting conservatism. An important basis for the criticism is the negative association observed between AT and market-to-book ratio (MB), another proxy for conservatism. Drawing upon prior research, we hypothesize and find that the negative relationship is stronger in a more litigious environment, indicating that low MB is a proxy for elevated expected litigation cost. Therefore the negative association reflects the rational response of managers and auditors in applying greater conservatism to mitigate expected litigation cost that increases as MB dips below a threshold. The negative association is not a valid basis for questioning the validity of the Basu model. This study demonstrates that MB is a proxy for risk, contributing to the debate on whether book-to-market ratio is a proxy for risk or the product of mispricing in the finance literature.
\end{abstract}

Keywords: Market-to-book, Book-to-market, Litigation, Asymmetric timeliness, Basu model, Conditional conservatism, Unconditional conservatism, Private Securities Litigation Reform Act

\section{Introduction}

Despite its long history and central role in accounting theory and practice, conservatism has neither an authoritative definition nor a non-controversial empirical measure (Givoly, Hayn, \& Natarajan, 2007). Recent studies (Dietrich, Muller, \& Riedl, 2007; Givoly et al., 2007) have questioned the validity of the widely-used asymmetric timeliness of earnings (AT) (Basu, 1997) in gauging the degree of conservatism. An important basis for the criticism is the negative association observed between AT and market-to-book ratio 
(MB), another proxy for conservatism (Ball, Kothari, \& Nikolaev, 2010 Roychowdhury \& Watts, 2007). Prior literature (Ball et al., 2010; Roychowdhury \& Watts, 2007) has fruitfully offered alternative explanations for the negative association to address the criticism. But existing explanations do not entertain the role of discretions and incentives although another strand of literature has demonstrated the essential role of incentives and discretions in financial reporting (Ball, Robin, \& Wu, 2003; Burgstahler, Hail, \& Leuz, 2006; Daske, Hail, Leuz, \& Verdi, 2008). In this study we offer an alternative incentives-based explanation for the negative MB-AT association. While previous explanations focus on the non-discretionary component, this study examines the discretionary component. (Note 1)

There are two related but distinct versions of conservatism: conditional and unconditional. But the distinction was not made until recently (Ball \& Shivakumar, 2005; Beaver \& Ryan, 2005). Basu (1997) and Watts (2003a) define conservatism as accountants' tendency to require a higher degree of verification for recognizing economic gains than economic losses in accounting earnings. This is referred to as conditional conservatism. This definition implies that in a regression of accounting earnings on economic earnings, accounting earnings reflect economic losses in a more timely manner than economic gains. This asymmetric timeliness of accounting earnings (AT) has been widely used as a premier measure of conditional conservatism (Ball et al., 2010; Ryan, 2006). The use of market-to-book ratio (MB) as the proxy for conservatism is based on the definition of conservative accounting suggested by the theoretical framework developed by Feltham and Ohlson (1995, 1996) (Givoly \& Hayn, 2000). Feltham and Ohlson (1995) define accounting conservatism as the expected long-run understatement of the book value of a company's net assets relative to their market value. Feltham and Ohlson (1996) attribute the understatement to the use of accelerated accounting depreciation of property, plant and equipment relative to economic depreciation as well as delayed accounting recognition of positive net present values. This is referred to as unconditional conservatism. $\mathrm{MB}$ is used to gauge the degree of that understatement as the proxy for unconditional conservatism (Beaver \& Ryan, 2005; Feltham \& Ohlson, 1995, 1996). To the extent that equity valuation by investors is based on the present value of future cash flows, MB would be higher when accounting measurements are more conservative (Feltham \& Ohlson, 1995, 1996; Givoly \& Hayn, 2000; Watts, 2003b). (Note 2)

MB is also a proxy for growth opportunities and financial distress. In fact, prior literature suggests that lowMB firms are likely to face higher expected litigation cost than high-MB firms (we elaborate on this in Section II). Another line of literature suggests that shareholder litigation concerns motivate managers and auditors to be more conservative in preparing financial statements (Ball, Kothari, \& Robin, 2000; Chung \& Wynn, 2008; DeFond \& Subramanyam, 1998; Huijgen \& Lubberink, 2005; Khan \& Watts, 2009; Watts, 2003a, 2003b). Hence, higher (lower) expected litigation cost of low-MB (high-MB) firms induces greater (less) conditional conservatism, engendering the negative association between MB and AT. Therefore our hypothesis is that the negative MB-AT relationship is stronger when the expected litigation cost is higher in a more litigious environment and vice versa.

To test our hypothesis, we compare the MB-AT relationship for the US firms before and after an exogenous legal regime change. We also conduct cross-sectional analysis to compare the relationship for US firms in the industries more prone to shareholder lawsuits versus firms in other industries. Finally, using a difference-indifferences design, we compare the changes in the relationship to see whether the changes are more pronounced for litigation-prone industry firms following the legal regime change. Empirical results are generally consistent with the hypothesis that higher levels of litigiousness enhance the negative association between MB and AT. (Note 3)

By documenting a direct, causal relationship, via an exogenous shock to the legal regime, between litigation and the MB-AT relationship, this study demonstrates that MB, beyond a proxy for conservatism, is negatively related to expected litigation cost. The negative MB-AT association reflects the rational response of managers and auditors in applying greater conservatism to mitigate elevated expected litigation cost in low-MB scenarios. The negative MB-AT association is not a valid basis for questioning the validity of the Basu model.

Our incentives-based explanation is an important extension of existing mechanical explanations. Firms have discretions over whether and when to recognize losses and expenses given the same underlying economic 
conditions and changes in economic conditions (Beatty \& Weber, 2006). Ramanna and Watts (2007) find that, due to debt covenant and CEO reputation concerns, $69 \%$ of the firms with market indications of goodwill impairment fail to recognize impairment losses in compliance with SFAS 142 in a compelling scenario in which their MB ratios dip below one despite the public outcry over a series of scandals (e.g., Enron, Worldcom). We document that managers and auditors are more likely to recognize economic losses in accounting earnings in a highly litigious environment given the same underlying economic conditions as reflected in their $\mathrm{MB}$ ratios.

Second, this study is also related to Beaver and Ryan (2005) who develop a general model of conditional and unconditional conservatism under uncertainty to help structure and interpret the negative association. They argue that it is critical for accounting standard setters, researchers and teachers and users of financial reports to understand that negative association and its implications given the importance of conservatism in accounting. While Beaver and Ryan (2005) emphasize that discretionary behavior over either form of conservatism is fertile ground for future research, they choose to abstract away from discretions and incentives in their model. (Note 4)

Third, this study also highlights the public policy significance of securities class action lawsuits by differentiating the role of public SEC enforcement from the role of private enforcement in financial reporting. Prior literature (Huijgen \& Lubberink, 2005; Thornton, 2002) asserts that the SEC is more rigorous than its counterparts in other countries in enforcing accounting standards. However, private enforcement dwarfs public SEC enforcement (Coffee, 2006; Jackson, 2007). Since the SEC has limited resources, private litigation is a more effective deterrent preventing accounting fraud (Seligman, 1994). This study provides empirical evidence on that assertion by documenting variations in conditional conservatism given the same MB for firms exposed to high vs. low litigation risk while subject to the same SEC enforcement.

This study also contributes to the debate on whether shareholder litigation is an effective governance mechanism (Rogers \& Buskirk, 2009) by documenting the impact of alternative legal regimes on incentives and earnings properties. This study adds to the literature on the consequences of the controversial US Private Securities Litigation Reform Act enacted in 1995.

This study is also related to Gigler, Kanodia, \& Sapra (2009) and Chen, Hemmer, \& Zhang (2007). Gigler et al. (2009) argue that accounting conservatism actually reduces the efficiency of debt contracts. While Gigler et al. (2009) welcome the benefits of asymmetric timeliness (AT) in increasing the probability of low signals when the future is gloomy, they are concerned about the "false alarm" harm of AT in increasing the probability of low signals when the future is bright. We empirically show that AT increases the probability of low signals when the future is bright as reflected in high MB, confirming their conjecture. Their concern about false alarm is justified. We also demonstrate the benefits of AT in increasing the probability of low signals when the future is gloomy as reflected in low MB. However the increase in the probability of low signals when the future is gloomy far exceeds the "false alarm" increase in the probability of low signals when the future is bright. It suggests that the false alarm noise introduced by conservatism is more than offset by the reduction in earnings inflation, making accounting reports more informative about managerial actions and improving the contracting efficiency (Chen et al., 2007). (Note 5)

This study also contributes to the debate on whether the book-to-market ratio (BM) is a proxy for risk or the product of mispricing in the broad context of the market efficiency debate in the finance literature (Frankel \& Lee, 1998; Hahn, O’Neill, \& Swisher, 2010). Numerous studies (Dempsey, 2010; Fama \& French, 1992) have documented a robust positive association between BM and stock returns. A large number of studies (Daniel \& Titman, 1997; Fama \& French, 1993, 1996) have attempted to explain the BM effect. Demystifying the BM effect sheds light on whether using the popular Fama and French (1993) model as an asset pricing model is justified (Dempsey, 2010; Hahn et al., 2010). While this study does not directly address the question of why BM is correlated with excess returns, we demonstrate that BM is a proxy for litigation risk.

The paper continues as follows. Section II develops the hypothesis. Section III discusses methodology. Section IV presents empirical results followed by robustness tests in Section V. We conclude with a summary 
of the findings, limitations, and suggestions for future research in Section VI.

\section{Prior literature and hypothesis development}

Prior literature suggests that ex-ante litigation cost increases as MB dips below a threshold. In the finance literature, one prominent explanation of the book-to-market premium in returns is that high book-to-market (i.e., low MB) firms are assigned higher risk premium because of the greater distress risk (Fama \& French, 1993, 1995, 1996; Griffin \& Lemmon, 2002; Hahn et al., 2010). Vassalou and Xing (2004) show that BM acts as a proxy for default risk. Accounting literature has documented a link between financial distress and higher probabilities of shareholder lawsuits (Lys \&Watts, 1994; Shu, 2000; Stice, 1991). It suggests that exante litigation cost will increase as MB dips below a threshold.

Meanwhile, low MB reflects poor stock price performance over the past six years (Beaver \& Ryan, 1993). Investment losses from poor stock returns give investors incentives and legal basis to take legal actions against the firm, managers and auditors, among others, to recoup their losses. Poor stock price performance has been linked to higher probabilities of lawsuits (Johnson, Kasznik, \& Nelson, 2000, 2001; Shu, 2000). It suggests that ex-ante litigation cost will increase as MB dips below a threshold.

Additionally, low MB reflects low unconditional conservatism and signals higher likelihood of asset andlor earnings overstatement. For instance, the failure of accountants to write off assets whose value has dipped below their carrying values as required under GAAP can produce low MB (Penman, Richardson, \& Tuna, 2007). Overstatement of assets andlor earnings in low-MB scenarios facilitates shareholder lawsuits because investors could point to such overstatement as a pretext for launching lawsuits against the firm, managers and auditors to recoup their losses. It suggests that ex-ante litigation cost will increase as MB dips below a threshold.

Low MB is also consistent with the scarcity of lucrative growth opportunities (Roychowdhury \& Watts, 2007; Smith \& Watts, 1992). When growth slows or reverses as indicated by low MB, managers are tempted to inflate accounting numbers and maintain the appearance of consistent growth (Summers \& Sweeney, 1998). When firms are in distress as indicated by low MB, managers have stronger incentives to avoid recognizing economic losses that might trigger the violation of debt covenants and hurt stock prices restricting the financing ability of the firm. Empirically, Ramanna and Watts (2007) report that $69 \%$ of the firms fail to recognize goodwill impairment losses as required by SFAS 142 in a compelling scenario in which their MB ratios dip below one. It suggests that moral hazard and adverse selection incentives motivate managers to be less conservative when $\mathrm{MB}$ is low, pointing to a positive relationship between MB and AT and posing a challenge to the negative association documented in prior literature.

In summary, as MB declines, shareholders are more likely to suffer losses, and managers are tempted to hide bad news from investors (hence, less conditional conservatism) that, when revealed, will lead to even greater investment losses triggering lawsuits. Hence expected litigation cost will increase as MB dips below a threshold. Consistent with that conjecture, Lys and Watts (1994) report that the litigation sample MB drops substantially between the median wrongdoing year and the filing year; the litigation sample has lower MB compared with control sample in the filing year. Consequently, there exists an embedded litigation cost for low-MB firms.

When a legal regime change occurs, the embedded litigation cost will change for low-MB firms. Higher expected litigation cost in a highly litigious environment induces greater conditional conservatism (i.e., more timely recognition of losses) for low-MB firms, and vice versa. In a highly litigious environment, litigation plays a deterrent role and more than offsets moral hazard and adverse selection incentives (Watts, 2003a). The severe legal cost of exercising discretion to boost accounting earnings will dominate the benefit of postponing the recognition of economic losses in accounting earnings. In a less litigious environment, in contrast, the disciplinary effects of shareholder litigation are compromised and thus less likely to offset moral hazard and adverse selection incentives. Consistent with that argument, Kothari, Shu, and Wysocki (2009) document that managers have incentives to withhold bad news but such incentives are subdued in the presence of greater litigation risk. Therefore, our hypothesis is that the relationship between MB and AT is positively related to the level of litigiousness. (Note 6)

The exogenous US legal developments in the 1990s provide a quasi-experimental setting to test our 
hypothesis. In the early 1990s, the accounting profession was facing excessively litigious environment (Ali \& Kallapur, 2001; Gottlieb \& Doroshow, 2002; Solomon \& Berton, 1993). This led to intensive lobbying by accounting firms for significant legal reform that eventually led to the promulgation of the Private Securities Litigation Reform Act (the Act hereafter) in December 1995. The 1995 Act substantially revised the 1933 Securities Act and the 1934 Securities Exchange Act and increased restrictions on private litigants' ability to sue managers and professional advisors for investment losses from securities fraud (Ali \& Kallapur, 2001; Johnson et al., 2000). Along with a major Supreme Court decision in 1994, the Act significantly reduces the level of litigiousness (Ali \& Kallapur, 2001; Coffee, 2006; Geiger \& Raghunandan, 2001; Holthausen, 2009; Johnson et al., 2000; Lee \& Mande, 2003; Levine \& Pritchard, 1998; Mahoney, 2009; Seetharaman, Srinidhi, \& Swanson, 2005; Venuti, 2004). The Act, by weakening the disciplinary effects of shareholder litigation, even allegedly contributed to the accounting scandals (Greenberger, 2002). Given the decrease in litigiousness following the legal regime change, our first empirical hypothesis is as follows: (Note 7)

H1: The negative association between $M B$ and conditional conservatism weakens as the level of litigiousness decreases following the 1994 Supreme Court decision and the 1995 Act.

If our hypothesis is true, one should observe that positive relationship both over time and cross-sectionally whenever there are variations in the level of litigiousness. Corroborating evidence from both cross-sectional and inter-temporal changes analysis will enhance confidence in the results.

Certain industries are more vulnerable to securities litigation than others at a given time. Francis et al. (1994) find that four industries experience relatively high incidence of shareholder lawsuits. This way of classifying high vs. low shareholder litigation risk industries has been validated and used in many studies (Ali \& Kallapur, 2001; Field, Lowry, \& Shu, 2005; Johnson et al., 2000, 2001; Rogers \& Stocken, 2005; Shu, 2000). Those litigation-prone industries are most likely to be affected by the legal regime change (Ali \& Kallapur, 2001; Johnson et al., 2000, 2001). Hence, our second empirical hypotheses are as follows: (Note 8)

Hypothesis 2a: Prior to the 1994 Supreme Court decision and the 1995 Act, litigation-prone industry firms exhibit a stronger negative association between $M B$ and conditional conservatism.

Hypothesis 2b: Following the 1994 Supreme Court decision and the 1995 Act, litigation-prone industry firms will experience a greater decrease in the MB-conditional conservatism association than firms in other industries.

\section{Methodology}

\subsection{Measure of conditional conservatism}

We use the Basu (1997) asymmetric timeliness (AT) to measure conditional conservatism at the portfolio level. We estimate the Basu (1997) regression model as follows:

$$
X=\beta_{0}+\beta_{1} D+\beta_{2} R+\beta_{3}(D \times R)+\varepsilon
$$

where firm and time subscripts are omitted. $X$ is net income (loss) (Compustat \#172) reported in period $t$ divided by the market value of common equity (Compustat $\# 25 \times$ Compustat $\# 199$ ) in period $t-1$; $R$ is equal to annual stock returns for the year ending three months after the fiscal year end; $D$ is equal to one if $R$ is negative, zero otherwise. $R$ is used as a proxy for news or economic earnings, where positive returns proxy for good news or economic gains and negative returns proxy for bad news or economic losses. $\beta_{2}$ is an estimate of good news timeliness and $\beta_{3}$ is an estimate of asymmetric timeliness (AT) as the measure of conditional conservatism. A positive value for $\beta_{3}$ implies that accounting earnings are more timely in recognizing economic losses than economic gains. (Note 9)

\subsection{Empirical model}

To test H1, we estimate equation (2) for the samples before versus after the legal regime change, respectively:

$$
X=\beta_{0}+\beta_{1} D+\beta_{2} R+\beta_{3}(D \times R)+\beta_{4} L M B+\beta_{5}(\text { LMB x D })+\beta_{6}(\text { LMB x R })+\beta_{7}(\text { LMB x D x R })+\varepsilon
$$

where LMB is a dummy variable equal to one if the beginning MB is less than one, zero otherwise; all other variables are as previously defined. The coefficient $\beta_{7}$ will be positive for a negative association between MB 
and AT. H1 predicts that $\beta_{7}$ will decrease following the legal regime change. Like Ball and Shivakumar (2005), we make no predictions for other coefficients or changes in other coefficients. $\beta_{1}$ is the deflated earnings for high-MB firms with negative returns. $\beta_{2}$ is an estimate of good news timeliness for high-MB firms. $\beta_{3}$ is an estimate of asymmetric timeliness (AT) for high-MB firms. $\beta_{4}$ is the deflated earnings for lowMB firms relative to high-MB firms. $\beta_{5}$ is the deflated earnings for low-MB firms with negative returns relative to other firms. $\beta_{6}$ is the good news timeliness for low-MB firms relative to high-MB firms. (Note 10)

To test H2, we estimate equation (2) for litigation-prone industry firm-year observations versus other firmyear observations before and after the legal regime change, respectively. H2a predicts that litigation-prone industry firms will exhibit greater $\beta_{7}$ than firms in other industries. H2b predicts that the decrease in $\beta_{7}$ will be more pronounced for litigation-prone industry firms than for firms in other industries following the legal regime change.

\subsection{Data and sample selection}

Accounting data are downloaded from COMPUSTAT. Data on stock returns are obtained from Center for Research in Security Prices (CRSP). We delete firm-year observations that do not have all the required data items (i.e., $\mathrm{X}, \mathrm{R}$ and $\mathrm{MB}$ ) available for our analysis. We drop the financial services and utilities firms to eliminate the potential effects of the differences in the firms' regulatory environments. We compute annual returns (R) by compounding CRSP monthly stock returns, requiring that all 12 monthly CRSP returns be available. We drop the top and bottom $1 \%$ observations of deflated earnings $(\mathrm{X})$ and annual returns $(\mathrm{R})$ to mitigate the undue influence of outliers. The resulting sample consists of 24725 firm-year observations for 7 107 firms over the sample periods 1991-93 and 1996-98. We do not include 1994 and 1995 to eliminate any potential contamination of the 1994 Supreme Court decision and the 1995 Act.

\subsection{Descriptive statistics}

Panel A of Table 1 contains descriptive statistics. The 1996-98 sample firms are larger than the 1991-93 firms, consistent with inflation and growth. MV is similar to those reported in Pae, Thornton, \& Welker (2005) and LaFond and Watts (2008). MB is slightly greater after the legal regime change. We are interested in the changes in the association between AT and MB. The change in MB itself is not of particular concern to this study. MB is similar to the mean of 3.82 reported in Pae et al. (2005). The 1991-93 firms have more favorable stock performance than the 1996-98 firms. The favorable stock returns are associated with reduced probabilities of litigation for average individual firms, in contrast to the highly litigious macro-environment prior to the legal regime change. This works against our hypothesis based on higher average levels of litigation risk in the economy prior to the legal regime change.

Panel B of Table 1 reports pair-wise correlations, where the upper right (lower left) hand portion displays the Pearson product-moment (Spearman rank-order) correlations. The correlations are similar to those reported in Pae et al. (2005), Khan and Watts (2009), and LaFond and Watts (2008). For instance, $X$ and $R$ are positively correlated. $M V$ and $X$ are positively correlated. There is no significant correlation between MB and other variables in the top Pearson correlations but all those correlations become significant at the bottom Spearman rank correlations. This indicates the non-linear nature of the correlations between MB and other variables.

Table 1: Sample and descriptive statistics

Panel A: Descriptive statistics 


\begin{tabular}{llrrrr}
\multicolumn{7}{c}{$1991-93$ (Pre-Act) } & & & \\
\hline Variable & & $\mathrm{N}$ & Mean & Median & Std. \\
\hline MV & 10564 & 1083 & 79 & 4471 \\
\hline MB & & 10567 & 3.20 & 1.72 & 72.69 \\
\hline \multirow{3}{*}{$R$} & All firms & 10567 & 0.19 & 0.08 & 0.59 \\
\cline { 2 - 6 } & Good news firms & 6115 & 0.52 & 0.33 & 0.56 \\
\cline { 2 - 6 } & Bad news firms & 4452 & -0.26 & -0.22 & 0.19 \\
\hline \multirow{3}{*}{$X$} & All firms & 10567 & -0.03 & 0.04 & 0.26 \\
\cline { 2 - 6 } & Good news firms & 6115 & 0.02 & 0.06 & 0.21 \\
\cline { 2 - 6 } & Bad news firms & 4452 & -0.09 & 0.01 & 0.29 \\
\hline
\end{tabular}

1996-98 (Post-Act)

\begin{tabular}{llrrrr}
\hline Variable & & $\mathrm{N}$ & Mean & Median & Std. \\
\hline MV & & 14124 & 2025 & 141 & 10320 \\
\hline MB & & 14158 & 3.92 & 2.39 & 37.85 \\
\hline \multirow{3}{*}{$R$} & All firms & 14158 & 0.05 & -0.03 & 0.54 \\
\cline { 2 - 6 } & Good news firms & 6717 & 0.48 & 0.34 & 0.45 \\
\cline { 2 - 6 } & Bad news firms & 7441 & -0.34 & -0.32 & 0.22 \\
\hline \multirow{3}{*}{$X$} & All firms & 14158 & -0.01 & 0.04 & 0.15 \\
\cline { 2 - 6 } & Good news firms & 6717 & 0.03 & 0.06 & 0.13 \\
\cline { 2 - 6 } & Bad news firms & 7441 & -0.04 & 0.01 & 0.15 \\
\hline
\end{tabular}

Panel B: Correlation matrix (Pearson top and Spearman bottom)

\begin{tabular}{lrrrr}
\hline & $\mathrm{X}$ & $\mathrm{R}$ & $\mathrm{MV}$ & $\mathrm{MB}$ \\
\hline $\mathrm{X}$ & & $0.19^{* * *}$ & $0.06^{* * *}$ & -0.01 \\
\hline $\mathrm{R}$ & $0.39^{* * *}$ & & $0.05^{* * *}$ & 0.00 \\
\hline $\mathrm{MV}$ & $0.25^{* * *}$ & $0.21^{* * *}$ & & 0.00 \\
\hline $\mathrm{MB}$ & $-0.08^{* * *}$ & $-0.11^{* * *}$ & $0.30^{* * *}$ & \\
\hline
\end{tabular}

$* * *, * *, *$ statistically significant at $1 \%, 5 \%$ and $10 \%$, respectively.

$M V$, market value, is equal to the number of common shares outstanding times closing share price (Compustat \#199 $\times$ Compustat \#25) at the end of the fiscal year (in \$millions). MB is the ratio of market-tobook value of common equity at the beginning of fiscal year. $R$ is equal to annual stock returns for the year ending three months after the fiscal period end. $X$ is equal to net income (loss) for the year deflated by the market value at the beginning of the year.

\subsection{Normality tests}

We examine whether the dependent variable, deflated earnings $(X)$, and one major independent variable, annual return $(R)$, are normally distributed. Note that the other major independent variable, LMB, is a dummy variable allowing for non-linearity. Normally distributed random variables should have skewness of zero and kurtosis of three. $X$ has skewness of -3.73 (-2.14) and kurtosis of 23.27 (9.40) for 1991-93 (199698) firm-year observations; $R$ has skewness of 1.80 (1.11) and kurtosis of 8.24 (4.94) for 1991-93 (1996-98) firm-year observations. They are not quite normally distributed but are reasonably close to normality.

\section{Results}

We hypothesize that the negative relationship between $\mathrm{MB}$ and conditional conservatism is positively related to the level of litigiousness. Panel A of Table 2 presents the empirical results for the basic Basu model and the expanded model with MB, respectively. The results from the basic Basu (1997) model show a significant decrease in asymmetric timeliness (AT) (i.e., the coefficients on D x R) for all firms. The decrease in AT is consistent with the litigation explanation for conservatism and the decrease in the level of litigiousness following the legal regime change. The expanded model results confirm the negative association between AT and MB (i.e., the positive coefficients on $\mathrm{LMB} \times \mathrm{D} \times \mathrm{R}$ ). Consistent with $\mathrm{H} 1$, the results demonstrate a significant decrease in the negative association following the legal regime change. The negative association between AT and MB moderates in a less tight legal regime. Thus, H1 is supported. (Note 11)

Panel B and Panel C of Table 2 present empirical results consistent with H2. Consistent with prior literature, the results show negative relationships between $\mathrm{AT}$ and MB (i.e., positive coefficients on $L M B \times D \times R$ ). Consistent with $\mathrm{H} 2 \mathrm{a}$, litigation-prone industries show stronger MB-AT association especially prior to the legal regime change. The difference is statistically significant. H2a is supported. Consistent with the decrease 
in litigiousness following the legal regime change, Panel C shows a significant decrease in AT for high-MB firms. Consistent with H1, there are significant decreases in the MB-AT association for both litigation-prone industry firms and firms in other industries. Consistent with $\mathrm{H} 2 \mathrm{~b}$, the decrease in the MB-AT association for litigation-prone industries is about three times the decrease for other industries. The difference-in-differences is statistically significant. The more pronounced decrease for litigation-prone industries corroborates our $\mathrm{H} 1$ results and enhances confidence that the decrease in the MB-AT association is attributed to the decrease in the level of litigiousness following the legal regime change. In short, H2 is supported. (Note 12)

Table 2: Legal regime change and the MB-AT association

$$
\begin{gathered}
X=\beta_{0}+\beta_{1} D+\beta_{2} R+\beta_{3}(D \times R)+\varepsilon \\
X=\beta_{0}+\beta_{1} D+\beta_{2} R+\beta_{3}(D \times R)+\beta_{4} L M B+\beta_{5}(L M B \times D)+\beta_{6}(L M B \times R)+\beta_{7}(L M B \times D \times R)+\varepsilon
\end{gathered}
$$

\begin{tabular}{|c|c|c|c|c|c|c|}
\hline \multirow[b]{2}{*}{ Coefficients } & \multicolumn{3}{|c|}{ Basic Basu model } & \multicolumn{3}{|c|}{ Expanded model with MB } \\
\hline & $\begin{array}{l}\text { 1991-93 } \\
\text { (t-value) }\end{array}$ & $\begin{array}{l}1996-98 \\
\text { (t-value) }\end{array}$ & $\begin{array}{l}\text { Changes } \\
\text { (t-value) }\end{array}$ & $\begin{array}{l}\text { 1991-93 } \\
\text { (t-value) }\end{array}$ & $\begin{array}{r}1996-98 \\
\text { (t-value) }\end{array}$ & $\begin{array}{l}\text { Changes } \\
\text { (t-value) }\end{array}$ \\
\hline Intercept & $\begin{array}{r}0.01 \\
(4.01)\end{array}$ & $\begin{array}{r}0.03 \\
(13.51)\end{array}$ & $\begin{array}{r}0.02 \\
(4.01)\end{array}$ & $\begin{array}{r}0.04 \\
(12.06)\end{array}$ & $\begin{array}{r}0.03 \\
(14.48)\end{array}$ & $\begin{array}{r}-0.01 \\
(-0.17)\end{array}$ \\
\hline $\mathrm{D}$ & $\begin{array}{r}-0.00 \\
(-0.18)\end{array}$ & $\begin{array}{r}-0.01 \\
(-1.84)\end{array}$ & $\begin{array}{r}-0.01 \\
(-0.66)\end{array}$ & $\begin{array}{r}0.00 \\
(0.71)\end{array}$ & $\begin{array}{r}-0.00 \\
(-0.69)\end{array}$ & $\begin{array}{r}-0.00 \\
(-0.97)\end{array}$ \\
\hline $\mathrm{R}$ & $\begin{array}{r}0.00 \\
(0.36)\end{array}$ & $\begin{array}{r}-0.00 \\
(-0.24)\end{array}$ & $\begin{array}{r}-0.00 \\
(-0.44)\end{array}$ & $\begin{array}{r}0.00 \\
(0.55)\end{array}$ & $\begin{array}{r}-0.00 \\
(-0.37)\end{array}$ & $\begin{array}{r}-0.00 \\
(-0.66)\end{array}$ \\
\hline $\mathrm{D} \times \mathrm{R}$ & $\begin{array}{r}0.40 \\
(13.72) \\
\end{array}$ & $\begin{array}{r}0.20 \\
(20.09) \\
\end{array}$ & $\begin{array}{r}-0.20 \\
(-6.58)\end{array}$ & $\begin{array}{r}0.28 \\
(13.29)\end{array}$ & $\begin{array}{r}0.18 \\
(19.81)\end{array}$ & $\begin{array}{r}-0.10 \\
(-4.16) \\
\end{array}$ \\
\hline LMB & & & & $\begin{array}{r}-0.08 \\
(-6.74)\end{array}$ & $\begin{array}{r}-0.01 \\
(-1.06)\end{array}$ & $\begin{array}{r}0.07 \\
(4.31)\end{array}$ \\
\hline $\mathrm{LMB} \times \mathrm{D}$ & & & & $\begin{array}{r}0.00 \\
(0.15)\end{array}$ & $\begin{array}{r}-0.03 \\
(-1.52)\end{array}$ & $\begin{array}{r}-0.03 \\
(-0.98)\end{array}$ \\
\hline $\mathrm{LMB} \times \mathrm{R}$ & & & & $\begin{array}{r}0.01 \\
(0.54)\end{array}$ & $\begin{array}{r}0.00 \\
(0.25)\end{array}$ & $\begin{array}{r}-0.01 \\
(-0.20)\end{array}$ \\
\hline $\mathrm{LMB} \times \mathrm{D} \times \mathrm{R}$ & & & & $\begin{array}{r}0.62 \\
(6.67)\end{array}$ & $\begin{array}{r}0.15 \\
(3.46)\end{array}$ & $\begin{array}{r}-0.47 \\
(-4.59)\end{array}$ \\
\hline $\mathrm{R}^{2}$ & 0.08 & 0.11 & & 0.17 & 0.13 & \\
\hline $\mathrm{N}$ & 10567 & 14158 & & 10567 & 14158 & \\
\hline
\end{tabular}

Panel A: Legal regime change and changes in the MB-AT association (H1)

Panel B: Cross-sectional and difference-in-differences analysis (H2)

\begin{tabular}{crrr}
\hline Samples & $\begin{array}{r}1991-93 \gamma \\
\text { (t-value })\end{array}$ & $\begin{array}{r}1996-98 \gamma \\
\text { (t-value })\end{array}$ & $\begin{array}{r}\text { Differences } \\
\text { (t-value) }\end{array}$ \\
\hline $\begin{array}{c}\text { Litigation-prone } \\
\text { Industries } \\
(\mathrm{n}=6 \text { 412) }\end{array}$ & $\begin{array}{r}1.11 \\
(5.05)\end{array}$ & 0.17 & -0.94 \\
$(1.98)$ & & \\
\hline $\begin{array}{c}\text { Other Industries } \\
(\mathrm{n}=18 \text { 313) }\end{array}$ & 0.47 & 0.16 & -0.31 \\
& $(4.86)$ & $(3.10)$ & $(-2.90)$ \\
\hline $\begin{array}{c}\text { Differences } \\
(\mathrm{t}-\mathrm{value})\end{array}$ & 0.64 & 0.01 & -0.63 \\
& $(2.67)$ & $(0.18)$ & $(-2.40)$
\end{tabular}

\begin{tabular}{|c|c|c|c|c|c|c|}
\hline \multicolumn{4}{|c|}{ Litigation-prone Industries } & \multicolumn{3}{|c|}{ Other Industries } \\
\hline Coefficients & $\begin{array}{l}\text { 1991-93 } \\
\text { (t-value) }\end{array}$ & $\begin{array}{l}1996-98 \\
\text { (t-value) }\end{array}$ & $\begin{array}{r}\text { Differences } \\
\text { (t-value) }\end{array}$ & $\begin{array}{l}1991-93 \\
\text { (t-value) }\end{array}$ & $\begin{array}{l}1996-98 \\
\text { (t-value) }\end{array}$ & $\begin{array}{r}\text { Differences } \\
(\mathrm{t}-\mathrm{v} \text { alue })\end{array}$ \\
\hline Intercept & $\begin{array}{r}0.04 \\
(6.55)\end{array}$ & $\begin{array}{r}0.03 \\
(7.55)\end{array}$ & $\begin{array}{r}-0.01 \\
(-1.08)\end{array}$ & $\begin{array}{r}0.03 \\
(10.32)\end{array}$ & $\begin{array}{r}0.03 \\
(12.01)\end{array}$ & $\begin{array}{r}-0.00 \\
(-0.33) \\
\end{array}$ \\
\hline $\mathrm{D}$ & $\begin{array}{r}-0.01 \\
(-0.49) \\
\end{array}$ & $\begin{array}{r}-0.02 \\
(-2.40) \\
\end{array}$ & $\begin{array}{r}-0.01 \\
(-0.79) \\
\end{array}$ & $\begin{array}{r}0.01 \\
(1.14) \\
\end{array}$ & $\begin{array}{r}0.00 \\
(1.17) \\
\end{array}$ & $\begin{array}{r}-0.01 \\
(-0.26) \\
\end{array}$ \\
\hline $\mathrm{R}$ & $\begin{array}{r}0.01 \\
(0.72) \\
\end{array}$ & $\begin{array}{r}-0.02 \\
(-2.18) \\
\end{array}$ & $\begin{array}{r}-0.03 \\
(-2.04) \\
\end{array}$ & $\begin{array}{r}-0.00 \\
(-0.09) \\
\end{array}$ & $\begin{array}{r}0.01 \\
(2.48) \\
\end{array}$ & $\begin{array}{r}0.01 \\
(1.62) \\
\end{array}$ \\
\hline $\mathrm{D} \times \mathrm{R}$ & 0.25 & 0.18 & -0.07 & 0.30 & 0.18 & -0.12 \\
\hline
\end{tabular}

Panel C: Detailed results for $\mathrm{H} 2$ 


\begin{tabular}{lrrrrrr}
\hline & $(6.31)$ & $(10.06)$ & $(-1.68)$ & $(11.76)$ & $(16.80)$ & $(-4.31)$ \\
\hline \multirow{2}{*}{$\mathrm{LMB}$} & -0.11 & -0.05 & 0.06 & -0.07 & 0.01 & 0.08 \\
& $(-4.31)$ & $(-2.51)$ & $(1.65)$ & $(-5.39)$ & $(0.57)$ & $(4.39)$ \\
\hline \multirow{2}{*}{$\mathrm{LMB} \times \mathrm{D}$} & 0.12 & 0.02 & -0.10 & -0.03 & -0.04 & -0.01 \\
& $(2.23)$ & $(0.50)$ & $(-1.60)$ & $(-1.15)$ & $(-2.23)$ & $(-0.37)$ \\
\hline \multirow{2}{*}{$\mathrm{LMB} \times \mathrm{R}$} & 0.03 & 0.05 & 0.02 & 0.01 & -0.02 & -0.03 \\
& $(0.92)$ & $(1.42)$ & $(0.48)$ & $(0.31)$ & $(-0.93)$ & $(-0.87)$ \\
\hline \multirow{2}{*}{$\mathrm{LMB} \times \mathrm{D} \times \mathrm{R}$} & 1.11 & 0.17 & -0.94 & 0.47 & 0.16 & -0.31 \\
& $(5.05)$ & $(1.98)$ & $(-3.97)$ & $(4.86)$ & $(3.10)$ & $(-2.90)$ \\
\hline $\mathrm{R}$ & 0.23 & 0.13 & & 0.15 & 0.13 & \\
\hline $\mathrm{N}$ & 2521 & 3891 & & 8046 & 10267 & \\
\hline
\end{tabular}

$D$ is an indicator variable equal to 1 if $R$ is negative and 0 otherwise. $L M B$ is a dummy variable equal to one if lagged $M B$ is less than one, zero otherwise. Litigation-prone industries are as follows: Computers (SIC codes 3570-3577 and 7370-7374), electronics (SIC Codes 3600-3674), and retail (SIC codes 5200-5961). All $t$-statistics are based on cluster analysis at the firm level to correct for standard errors as each firm contributes more than one observation. Results remain intact with cluster analysis at the firm-year level.

In summary, the above results demonstrate a significant decrease in the negative association between $\mathrm{MB}$ and conditional conservatism, as the level of litigiousness decreases following the legal regime change. The $\mathrm{H} 2$ results based on the cross-sectional analysis and the difference-in-differences design confirm the H1 results from the inter-temporal changes analysis. The exogenous shock to the legal regime makes this positive link interpretable as a causal relationship as opposed to an empirical association. However, additional factors need to be considered before reaching a conclusion. We present the results from robustness tests next.

\section{Additional analysis}

\subsection{Alternative low-MB definitions}

Recall that we define "low" MB as lagged MB being less than one in our tests. This definition is particularly interesting because, with MB being less than one, net assets are carried at more than their going concern value for accounting purposes. We can observe how managers exercise their discretion over conditional conservatism in response to asset impairment and how auditors might play their policing role differently given the changes in the level of litigiousness related to the legal regime change.

However, another potential confounding factor is that MB tends to vary across industries. For instance, one might argue that firms in fast-growing high-tech industries typically have fewer tangible assets and higher MB yet still face elevated levels of litigation risks. We argue that high-MB firms in high-tech industries will face negligible risk of litigation when they enjoy strong stock price performance and recognize bad news in a timely manner. Low-MB firms in high-tech industries prone to lawsuits are likely to face higher levels of litigation risk compared with low-MB firms in other industries. Nevertheless we repeat our analysis using the industry median MB as the cutoff to address the concern. That is, firms whose beginning MB falls below industry median are classified as low-MB. Table 3 shows that our primary results are robust to this robustness test. Consistent with $\mathrm{H} 1$, the results from this robustness test show a significant decrease in the MB-AT association following the legal regime change. Untabulated results also support $\mathrm{H} 2 \mathrm{a}(t=1.86)$ and $\mathrm{H} 2 \mathrm{~b}(t=-1.90)$.

We also repeat our analysis by allocating firm-year observations to quintiles based on the lagged $\mathrm{MB}$. We also use the top two quintiles as high-MB firms and bottom two quintiles as low-MB firms. The results are robust to these alternative definitions of "low" MB firms. The results remain intact when we use the same MB cutoffs before and after the legal regime change. We also drop those firms whose lagged MB dip below one when we use the industry median $\mathrm{MB}$ as the cutoff, results are similar. It suggests that the results are not exclusively driven by those firms whose lagged MB are less than one. These results remain intact using the industry level analysis.

\subsection{Industry level analysis}

We repeat our analysis at the industry level to alleviate measurement error concerns with the Basu model. Givoly et al. (2007) and Ryan (2006) argue that industry level analysis is one feasible way to address some 
of the concerns with the Basu measure. Table 3 also presents the industry level results. Like the primary results, the results from this robustness test show negative relationships between MB and AT (i.e., the positive coefficients on LMB $\times \mathrm{D} \times \mathrm{R}$ ). Again, the results show a significant decrease in the MB-AT relationship, supporting our hypothesis that the MB-AT relationship is positively related to the level of litigiousness. Untabulated results also support $\mathrm{H} 2 \mathrm{a}(t=2.62)$ and $\mathrm{H} 2 \mathrm{~b}(t=-2.46)$. In short, our primary results are robust to the industry level analysis. (Note 13)

Table 3: Robustness tests

$$
X=\beta_{0}+\beta_{1} D+\beta_{2} R+\beta_{3}(D \times R)+\beta_{4} L M B+\beta_{5}(L M B \times D)+\beta_{6}(L M B \times R)+\beta_{7}(L M B \times D \times R)+\varepsilon
$$

\begin{tabular}{|c|c|c|c|c|c|c|}
\hline \multicolumn{4}{|c|}{ MB cutoff at industry median } & \multicolumn{3}{|c|}{ Industry level analysis } \\
\hline Coefficient & $\begin{array}{l}1991-93 \\
\text { (t-value) }\end{array}$ & $\begin{array}{l}1996-98 \\
\text { (t-value) }\end{array}$ & $\begin{array}{l}\text { Differences } \\
\text { (t-value) }\end{array}$ & $\begin{array}{l}1991-93 \\
\text { (t-value) }\end{array}$ & $\begin{array}{l}1996-98 \\
\text { (t-value) }\end{array}$ & $\begin{array}{c}\text { Differences } \\
\text { (t-value) }\end{array}$ \\
\hline Intercept & $\begin{array}{r}0.04 \\
(11.38)\end{array}$ & $\begin{array}{r}0.03 \\
(11.15)\end{array}$ & $\begin{array}{r}-0.01 \\
(-0.81)\end{array}$ & $\begin{array}{r}0.03 \\
(8.62)\end{array}$ & $\begin{array}{r}0.03 \\
(10.51)\end{array}$ & $\begin{array}{r}-0.00 \\
(-0.37)\end{array}$ \\
\hline $\mathrm{D}$ & $\begin{array}{r}-0.00 \\
(-0.32)\end{array}$ & $\begin{array}{r}-0.01 \\
(-2.37)\end{array}$ & $\begin{array}{r}-0.01 \\
(-1.12)\end{array}$ & $\begin{array}{r}0.01 \\
(1.43)\end{array}$ & $\begin{array}{r}0.00 \\
(0.76)\end{array}$ & $\begin{array}{r}-0.01 \\
(-0.76)\end{array}$ \\
\hline $\mathrm{R}$ & $\begin{array}{r}-0.01 \\
(-1.55)\end{array}$ & $\begin{array}{r}-0.02 \\
(-3.24)\end{array}$ & $\begin{array}{r}-0.01 \\
(-1.21)\end{array}$ & $\begin{array}{r}0.00 \\
(1.04)\end{array}$ & $\begin{array}{r}0.01 \\
(3.90)\end{array}$ & $\begin{array}{r}0.01 \\
(1.58)\end{array}$ \\
\hline $\mathrm{D} \times \mathrm{R}$ & $\begin{array}{r}0.23 \\
(10.96)\end{array}$ & $\begin{array}{r}0.16 \\
(14.88)\end{array}$ & $\begin{array}{r}-0.07 \\
(-3.03)\end{array}$ & $\begin{array}{r}0.30 \\
(9.35)\end{array}$ & $\begin{array}{r}0.16 \\
(13.48)\end{array}$ & $\begin{array}{r}-0.14 \\
(-4.00)\end{array}$ \\
\hline LMB & $\begin{array}{r}-0.04 \\
(-5.78)\end{array}$ & $\begin{array}{r}0.00 \\
(0.01) \\
\end{array}$ & $\begin{array}{r}0.04 \\
(4.84) \\
\end{array}$ & $\begin{array}{r}-0.08 \\
(-4.75)\end{array}$ & $\begin{array}{r}0.01 \\
(0.53) \\
\end{array}$ & $\begin{array}{r}0.09 \\
(3.84) \\
\end{array}$ \\
\hline $\mathrm{LMB} \times \mathrm{D}$ & $\begin{array}{r}0.02 \\
(1.20) \\
\end{array}$ & $\begin{array}{r}0.01 \\
(1.55) \\
\end{array}$ & $\begin{array}{r}-0.01 \\
(-0.39) \\
\end{array}$ & $\begin{array}{r}-0.01 \\
(-0.45) \\
\end{array}$ & $\begin{array}{r}-0.04 \\
(-1.76) \\
\end{array}$ & $\begin{array}{r}-0.03 \\
(-0.69) \\
\end{array}$ \\
\hline $\mathrm{LMB} \times \mathrm{R}$ & $\begin{array}{r}0.02 \\
(1.88)\end{array}$ & $\begin{array}{r}0.03 \\
(3.72)\end{array}$ & $\begin{array}{r}0.01 \\
(0.66)\end{array}$ & $\begin{array}{r}0.01 \\
(0.41)\end{array}$ & $\begin{array}{r}-0.03 \\
(-0.79)\end{array}$ & $\begin{array}{r}-0.04 \\
(-0.88)\end{array}$ \\
\hline $\mathrm{LMB} \times \mathrm{D} \times \mathrm{R}$ & $\begin{array}{r}0.47 \\
(7.80) \\
\end{array}$ & $\begin{array}{r}0.09 \\
(4.84) \\
\end{array}$ & $\begin{array}{r}-0.38 \\
(-5.95) \\
\end{array}$ & $\begin{array}{r}0.45 \\
(3.64) \\
\end{array}$ & $\begin{array}{r}0.19 \\
(2.82) \\
\end{array}$ & $\begin{array}{r}-0.26 \\
(-1.87) \\
\end{array}$ \\
\hline $\mathrm{R}^{2}$ & 0.13 & 0.12 & & 0.13 & 0.14 & \\
\hline $\mathrm{N}$ & 10567 & 14158 & & 5802 & 7539 & \\
\hline
\end{tabular}

\subsection{Alternative firm-year observations}

When we compare 1992-93 vs. 1996-97, the decrease in the MB-AT relationship is $-0.25(t=-2.66)$. When we compare 1991-92 vs. 1996-97, the decrease is $-0.58(t=-5.40)$. In contrast, when we compare 1990-91 vs. 1992-93, there is no significant change observed in the MB-AT relationship when we do not expect any meaningful change in the level of litigiousness from 1990-91 to 1992-93. This indirect evidence is consistent with the primary results.

\subsection{Additional controls}

We control for ending MB (EMB), contracting (LEV), firm size (SIZE) and information asymmetry that also influence conditional conservatism. Table 4 reports the results after controlling for ending MB and LEV. Consistent with LaFond and Watts (2008), the coefficients on LEV x D x R are positive. Again, the coefficients on LMB $\times$ D $x$ R are positive. Consistent with our hypothesis, the coefficients on LMB $\times$ D $\times R$ experience a significant decrease of $80 \%$ from 0.57 to 0.11 following the legal regime change. Untabulated results show that the primary results are also robust to controls for ending MB and LEV for $\mathrm{H} 2 \mathrm{a}(t=2.74)$ and $\mathrm{H} 2 \mathrm{~b}(t=-2.51)$. In summary, the primary results are robust to controls for ending MB and LEV.

Table 4: Controls for ending MB and LEV

\begin{tabular}{lrrr}
\hline Coefficient & $\begin{array}{r}1991-93 \\
(\mathrm{t}-\mathrm{value})\end{array}$ & $\begin{array}{r}1996-98 \\
(\mathrm{t}-\mathrm{value})\end{array}$ & $\begin{array}{r}\text { Difference } \\
(\mathrm{t}-\text { value })\end{array}$ \\
\hline \multirow{2}{*}{ Intercept } & 0.06 & 0.04 & -0.02 \\
& $(7.94)$ & $(11.66)$ & $-2.68)$ \\
\hline \multirow{2}{*}{$\mathrm{D}$} & -0.01 & -0.00 & 0.01 \\
& $(-0.58)$ & $(-0.52)$ & $(0.34)$ \\
\hline \multirow{2}{*}{$\mathrm{R}$} & 0.01 & 0.01 & -0.00 \\
& $(0.73)$ & $(1.21)$ & $(-0.24)$ \\
\hline \multirow{2}{*}{$\mathrm{D} \times \mathrm{R}$} & 0.21 & 0.15 & -0.06 \\
& $(5.84)$ & $(11.96)$ & $(-1.43)$ \\
\hline
\end{tabular}




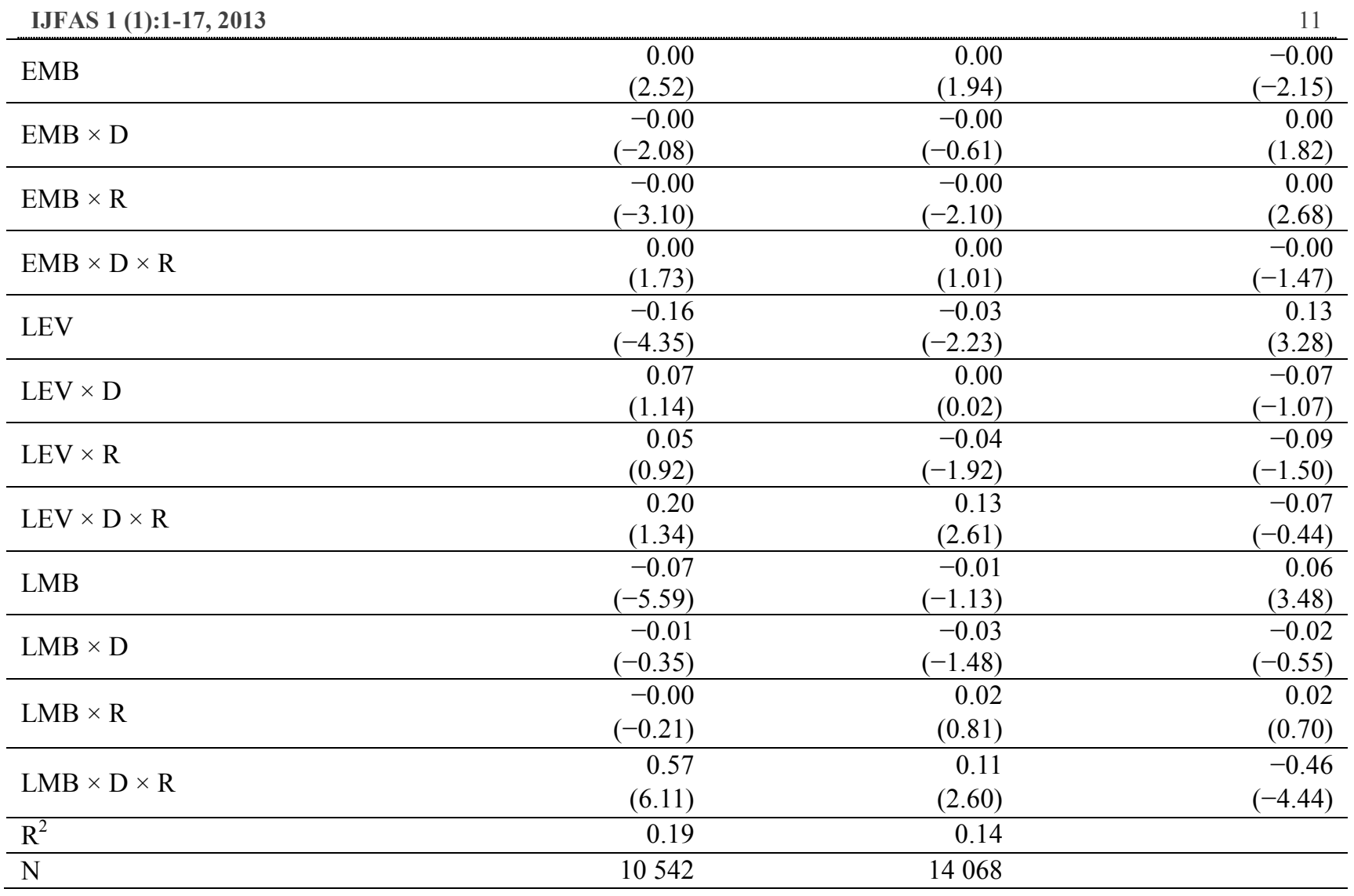

EMB, the ending market to book ratio, is defined as the market value of equity (Compustat \#199 $\times$ Compustat \#25) divided by the book value of equity (Compustat \# 60) at the end of the fiscal year. LEV, leverage, is defined as total debt (Compustat \#9+Compustat \#34) divided by total assets (Compustat \#6) at the end of the fiscal year.

In untabulated analysis, the primary results are robust to controls for ending MB, LEV, and SIZE for both hypotheses. Consistent with Givoly et al. (2007) and LaFond and Watts (2008), SIZE is negatively related to AT. Consistent with LaFond and Watts (2008), LEV and ending MB are positively related to AT. Again, the results show a significant decrease in the MB-AT relationship of $-0.39(t=-3.87)$, supporting H1. The results also support $\mathrm{H} 2 \mathrm{a} \quad(t=2.52)$ and $\mathrm{H} 2 \mathrm{~b}(t=-2.33)$. The primary results are also robust to controls for ending MB, LEV, and bid-ask spread ( $t=-4.11$ for $\mathrm{H} 1 ; t=1.97$ for $\mathrm{H} 2 \mathrm{a} ; t=-1.64$ for $\mathrm{H} 2 \mathrm{~b}$ ) as well as to controls for ending MB, LEV, bid-ask spread and SIZE $(t=-4.05$ for H1; $t=1.86$ for H2a; $t=-1.60$ for $\mathrm{H} 2 \mathrm{~b}$ ). In short, our primary results are robust to controls for the variables that have been found to influence conditional conservatism in prior literature.

\subsection{Alternative measure of conditional conservatism}

Untabulated results show that the $\mathrm{H} 1$ result is robust when we repeat our analysis using a firm-year measure of asymmetric timeliness, C_score (Khan \& Watts, 2009). Sample construction and C_score computation follow Khan and Watts (2009). Again, the MB-AT relationship experiences a significant decrease of about $50 \%$. The decrease is statistically significant $(t=-9.88)$. Unfortunately, we do not find support for either $\mathrm{H} 2 \mathrm{a}$ or $\mathrm{H} 2 \mathrm{~b}$ using the $\mathrm{C} \_$score. In short, the results are mixed using the $\mathrm{C} \_$score measure.

In summary, empirical results confirm the negative association between MB and conditional conservatism. Overall results point to an overall weakening in that association as the level of litigiousness decreases following the legal regime change. It suggests that litigation exerts some impact on the association between MB and conditional conservatism.

\section{Conclusion and discussion}

Prior literature suggests that low-MB firms are likely to face higher expected litigation cost than high-MB firms. Another strand of research demonstrates that shareholder litigation concerns motivate managers and auditors to be more conservative in preparing financial statements as conservatism reduces expected litigation cost. We tie together the two lines of literature and argue that higher expected litigation cost of low- 
MB firms induces greater conditional conservatism, engendering the negative MB-AT association. If this argument is plausible, the MB-AT association will be stronger in a more litigious environment and vice versa. We test our hypothesis using a quasi-experimental setting characterized by a US legal regime change - a 1994 US Supreme Court decision and the 1995 Private Securities Litigation Reform Act. Empirical results based on the 1991-93 vs. 1996-98 firm-year observations point to a positive relationship between MB-AT association and the level of litigiousness.

The results demonstrate that MB, beyond a proxy for conservatism, is negatively related to expected litigation cost. The negative MB-AT association reflects the rational response of managers and auditors in applying greater conservatism to mitigate elevated expected litigation cost in low-MB scenarios. This is consistent with shareholder litigation being one of the major determinants of conservatism (Watts, 2003a, 2003b) and with the notion that auditor and manager incentives affect accounting choices (Watts \& Zimmerman, 1986). The negative association between MB and AT is not a valid basis for questioning the validity of the Basu model. The evidence that conditional conservatism is reduced in a less tight legal regime even when write-downs are warranted in low-MB scenarios (e.g., $\mathrm{MB}<1$ ) is particularly relevant for the International Accounting Standards Board (IASB) since there are significant variations in the legal regimes around the world.

This study has its own share of limitations. For instance, prior literature documents positive associations between accounting conservatism and shareholder litigation. However, there is no theory or evidence to support the assumption that the relation between conservatism and litigation is linear. Verifying that assumption is left for future research. Future research could build on our results by testing for cross-sectional differences in the MB-AT association across countries with differing degrees of expected litigation costs. Future research could examine the impact of other incentives. Future research could also test to see whether there is any residual negative, mechanical association between MB and AT in countries with negligible expected litigation costs.

\section{References}

Ali, A., \& Kallapur, S. (2001). Securities price consequences of the Private Securities Litigation Reform Act and related events. The Accounting Review, 76(3), 431-460. http://dx.doi.org/10.2308/accr.2001.76.3.431

Avery, T. (1996). Securities litigation reform: The long and winding road to the Private Securities Litigation Reform Act of 1995. The Business Lawyer, 51, 335-378.

Ball, R., Kothari, S. R., \& Robin, A. (2000). The effect of international institutional factors on properties of accounting earnings. Journal of Accounting and Economics 29, 1-51. http://dx.doi.org/10.1016/S0165$\underline{4101(00) 00012-4}$

Ball, R., Kothari, S. P., \& Nikolaev, V. (2010). Econometrics of the Basu asymmetric timeliness coefficient and accounting conservatism. Chicago Booth Research Paper No. 09-16. [Online] Available at SSRN: http://ssrn.com/abstract $=999710$

Ball, R., Robin, A., \& Wu, J. S. (2003). Incentives versus standards: Properties of accounting income in four East Asian countries. Journal of Accounting and Economics, 36, 235-270. http://dx.doi.org/10.1016/j.jacceco.2003.10.003

Ball, R., \& Shivakumar, L. (2005). Earnings quality in UK private firms: Comparative loss recognition timeliness.

Journal of Accounting and Economics, 39, 83-128. http://dx.doi.org/10.1016/j.jacceco.2004.04.001

Basu, S. (1997). The conservatism principle and the asymmetric timeliness of earnings. Journal of Accounting and Economics, 24, 3-37. http://dx.doi.org/10.1016/S0165-4101(97)00014-1

Beatty, A. and J. Weber. (2006). Accounting Discretion in Fair Value Estimates: An Examination of SFAS 142 Goodwill Impairments. Journal of Accounting Research 44, 257-288. http://dx.doi.org/10.1111/j.1475$\underline{679 X .2006 .00200 . x}$ 
Beaver, W. H., \& Ryan, S. G. (1993). Accounting fundamentals of the book-to-market ratio. Financial Analysts Journal, November-December, 50-56. http://dx.doi.org/10.2469/faj.v49.n6.50

Beaver, W., \& Ryan, S. (2005). Conditional and unconditional conservatism: Concepts and modeling. Review of Accounting Studies, 10, 269-309. http://dx.doi.org/10.1007/s11142-005-1532-6

Burgstahler, D., Hail, L., \& Leuz, C. (2006). The importance of reporting incentives: Earnings management in European private and public firms. The Accounting Review, 81(5), 983-1016. http://dx.doi.org/10.2308/accr.2006.81.5.983

Chen, Q., Hemmer, T. \& Zhang, Y. (2007). On the relation between conservatism in accounting standards and incentives for earnings management. Journal of Accounting Research, 45, 541-565. http://dx.doi.org/10.1111/j.1475-679X.2007.00243.x

Chung, H. H., \& Wynn, J. P. (2008). Managerial legal liability coverage and earnings conservatism. Journal of Accounting and Economics, 46, 135-153. http://dx.doi.org/10.1016/j.jacceco.2008.03.002

Coffee, J. C. (2006). Reforming the securities class action: An essay on deterrence and its implementation. Columbia Law Review, 106, 1534-1586.

Daniel, K., \& Titman, S. (1997). Evidence on the characteristics of cross sectional variation in stock returns. The Journal of Finance, 52, 1-33. http://dx.doi.org/10.1111/j.1540-6261.1997.tb03806.x

Daske, H., Hail, L., Leuz, C., \& Verdi, R. (2008). Mandatory IFRS reporting around the world: Early evidence on the economic consequences. Journal of Accounting Research, 46 (5), 1085-1142.

DeFond, M. L., \& Subramanyam, K. R. (1998). Auditor changes and discretionary accruals. Journal of Accounting and Economics, 25, 35-67. http://dx.doi.org/10.1016/S0165-4101(98)00018-4

Dempsey, M. (2010). The book-to-market equity ratio as a proxy for risk: Evidence from Australian markets. Australian Journal of Management, 35(1), 7-21. http://dx.doi.org/10.1177/0312896209351451

Dietrich, D., Muller, K., \& Riedl, E. (2007). Asymmetric timeliness tests of accounting conservatism. Review of Accounting Studies, 12, 95-124. http://dx.doi.org/10.1007/s11142-006-9023-y

Fama, E., \& French, K. R. (1992). The cross-section of expected returns. The Journal of Finance, 47(2), 427-465. http://dx.doi.org/10.1111/j.1540-6261.1992.tb04398.x

Fama, E. F., \& French, K. (1993). Common risk factors in the returns of stocks and bonds. Journal of Financial Economics, 33, 3-56. http://dx.doi.org/10.1016/0304-405X(93)90023-5

Fama, E. F., \& French, K. (1995). Size and book-to-market factors in earnings and returns. The Journal of Finance, 50, 131-155. http://dx.doi.org/10.1111/j.1540-6261.1995.tb05169.x

Fama, E. F., \& French, K. (1996). Multi-factor explanations of asset pricing anomalies. The Journal of Finance, 51, 55-84. http://dx.doi.org/10.1111/j.1540-6261.1996.tb05202.x

Feltham, G. A., \& Ohlson, J. A. (1995). Valuation and clean surplus accounting for operating and financial activities. Contemporary Accounting Research, 11, 689-731. http://dx.doi.org/10.1111/j.1911$\underline{3846.1995 . t b 00462 . x}$

Feltham, G. A., \& Ohlson, J. A. (1996). Uncertainty resolution and the theory of depreciation measurement. Journal of Accounting Research, 34, 209-234. http://dx.doi.org/10.2307/2491500

Field, L., Lowry, M., \& Shu, S. (2005). Does disclosure deter or trigger litigation? Journal of Accounting and Economics, 39, 487-507. http://dx.doi.org/10.1016/j.jacceco.2005.04.004

Francis, J., Philbrick, D., \& Schipper, K. (1994). Shareholder litigation and corporate disclosures. Journal of Accounting Research, 32 (2), 137-164. http://dx.doi.org/10.2307/2491279

Frankel, R., \& Lee, C. (1998). Accounting valuation, market expectation, and the book-to-market effect. Journal of Accounting and Economics, 25, 283-321. http://dx.doi.org/10.1016/S0165-4101(98)00026-3

Geiger, M. A., \& Raghunandan, K. (2001). Bankruptcies, audit reports, and the reform act. Auditing: A Journal of Practice and Theory, 20 (1), 187-195. http://dx.doi.org/10.2308/aud.2001.20.1.187 
Gigler, F., Kanodia, C., Sapra, H., \& Venugopalan, R. (2009). Accounting conservatism and the efficiency of debt contracts. Journal of Accounting Research, 47 (3), 767-797. http://dx.doi.org/10.1111/j.1475$\underline{679 X .2009 .00336 . X}$

Givoly, D., \& Hayn, C. (2000). The changing time-series properties of earnings, cash flows, and accruals: Has financial reporting become more conservative? Journal of Accounting and Economics, 29, 287-320. http://dx.doi.org/10.1016/S0165-4101(00)00024-0

Givoly, D., Hayn, C. K., \& Natarajan, A. (2007). Measuring reporting conservatism. The Accounting Review, 82 (1), 65-106. http://dx.doi.org/10.2308/accr.2007.82.1.65

Gottlieb, E., \& Doroshow, J. (2002). Not in my back yard II: The litigation-prone hypocrites of "tort reform". Center for Justice Democracy (April) .

Greenberger, R. S. (2002). Questioning the books: Panel, in Enron's Wake, to Review Lawsuit Curbs. The Wall Street Journal (February 6), A8.

Griffin, M. J., \& Lemmon, L. M. (2002). Book-to-market equity, distress risk and stock returns. The Journal of Finance, 57, 2317-2336. http://dx.doi.org/10.1111/1540-6261.00497

Hahn, T., O’Neill, M., \& Swisher, J. (2010). What does book-to-market proxy: Risk or investor sentiment? Academy of Accounting and Financial Studies Journal, 14 (3), 85-100.

Holthausen, R. W. (2009). Accounting standards, financial reporting outcomes and enforcement. Journal of Accounting Research, 47, 447-458. http://dx.doi.org/10.1111/j.1475-679X.2009.00330.x

Huijgen, C., \& Lubberink, M. (2005). Earnings conservatism, litigation and contracting: The case of crosslisted firms. Journal of Business Finance \& Accounting, 32, 1275-1309. http://dx.doi.org/10.1111/j.0306$\underline{686 X .2005 .00629 . x}$

Jackson, H. (2007). Variation in the intensity of financial regulation preliminary evidence and potential implications. Yale Journal On Regulation, 24 (2), 253-291.

Johnson, M. F., Kasznik, R., \& Nelson, K. K. (2000). Shareholder wealth effects of the Private Securities Litigation Reform Act of 1995. Review of Accounting Studies, 5, 217-233. http://dx.doi.org/10.1023/A:1009612610389

Johnson, M. F., Kasznik, R., \& Nelson, K. K. (2001). The impact of Securities Litigation Reform on the disclosure of forward-looking information by high technology firms. Journal of Accounting Research, 39 (2), 297-327. http://dx.doi.org/10.1111/1475-679X.00014

Khan, M., \& Watts, R. L. (2009). Estimation and empirical properties of a firm-year measure of conservatism. Journal of Accounting and Economics, 48, 132-150. http://dx.doi.org/10.1016/j.jacceco.2009.08.002

Kothari, S. P., Shu, S., \& Wysocki, P. D. (2009). Do managers withhold bad news? Journal of Accounting Research, 47, 241-276. http://dx.doi.org/10.1111/j.1475-679X.2008.00318.x

LaFond, R., \& Watts R. L. (2008). The information role of conservatism. The Accounting Review, 83, 447478. http://dx.doi.org/10.2308/accr.2008.83.2.447

Lee, H., \& Mande, V. (2003). The effect of the Private Securities Litigation Reform Act of 1995 on accounting discretion of client managers of big 6 and non-big-6 auditors. Auditing: A Journal of Practice and Theory, 22 (1), 93-108. http://dx.doi.org/10.2308/aud.2003.22.1.93

Levine, D., \& Pritchard, A. (1998). The Securities Litigation Uniform Standards Act of 1998: The sun sets on California's blue sky laws. Business Lawyer, 54, 1-54.

Lys, T., \& Watts, R. L. (1994). Lawsuits against auditors. Journal of Accounting Research, 32, 65-93. http://dx.doi.org/10.2307/2491440

Mahoney, P. G. (2009). The development of securities law in the United States. Journal of Accounting Research, 47, 325-347. http://dx.doi.org/10.1111/j.1475-679X.2009.00326.x 
Pae, J., Thornton, D., \& Welker, M. (2005). The link between earnings conservatism and the price to book ratio. Contemporary Accounting Research, 22 (3), 693-717. http://dx.doi.org/10.1506/9FDN-N6ED-LJE9$\underline{\mathrm{A} 1 \mathrm{HL}}$

Penman, S. H., Richardson, S. A., \& Tuna, I. (2007). The book-to-price effect in stock returns: Accounting for leverage. Journal of Accounting Research, 45 (2), 427-467. http://dx.doi.org/10.1111/j.1475$\underline{679 X .2007 .00240 . x}$

Pope, P., \& Walker, M. (1999). International differences in the timeliness, conservatism and classification of earnings. Journal of Accounting Research 37, 53-87. http://dx.doi.org/10.2307/2491345

Ramanna, K., \& Watts, R. L. (2007). Evidence on the effects of unverifiable fair-value accounting. Harvard Business School Working Paper No. 08-014. [Online] Available at SSRN: http://ssrn.com/abstract=1012139.

Rogers, J. L., \& Buskirk, A. V. (2009). Shareholder litigation and changes in disclosure behavior. Journal of Accounting and Economics, 47, 136-156. http://dx.doi.org/10.1016/j.jacceco.2008.04.003

Rogers, J., \& Stocken, P. (2005). Credibility of management forecasts. The Accounting Review, 80, 12331260. http://dx.doi.org/10.2308/accr.2005.80.4.1233

Roychowdhury, S., \& Watts, R. (2007). Asymmetric timeliness of earnings, market-to-book and conservatism in financial reporting. Journal of Accounting and Economics, 44 , 2-31.

http://dx.doi.org/10.1016/j.jacceco.2006.12.003

Ryan, S. G. (2006). Identifying conditional conservatism. European Accounting Review, 15, 511-525. http://dx.doi.org/10.1080/09638180601102099

Seligman, J. (1994). The merits do matter. Harvard Law Review, 108, 438-457. http://dx.doi.org/10.2307/1341897

Seetharaman, A., Srinidhi, B., \& Swanson, Z. (2005). The effect of the Private Securities Litigation Reform Act of 1995 on accounting conservatism. Journal of Accounting and Finance Research 13 (4), 11-26.

Shu, S. Z. (2000). Auditor resignations: clientele effects and legal liability. Journal of Accounting and Economics, 29, 173-205. http://dx.doi.org/10.1016/S0165-4101(00)00019-7

Smith, C. W., \& Watts, R. L. (1992), The investment opportunity set and corporate financing, dividend, and compensation policies. Journal of Financial Economics, 32 (3), 263-292. http://dx.doi.org/10.1016/0304405X(92)90029-W

Solomon, C., \& Berton, L. (1993). Deloitte is hit by jury award of $\$ 77$ million. Wall Street Journal, A4 (November 3).

Stice, J. (1991). Using financial and market information to identify pre-engagement factors associated with lawsuits against auditors. The Accounting Review, 66 (3), 516-533.

Summers, S.L., \& Sweeney, J.T.(1998). Fraudulently misstated financial statements and insider trading: An empirical analysis. The Accounting Review, 73 (1), 131-145.

Thornton, D. (2002). Testimony to the Canadian Standing Senate Committee on Banking, Trade, and Commerce.

Vassalou, M., \& Xing, Y. (2004). Default risk in equity returns. The Journal of Finance, 59, 831-68. http://dx.doi.org/10.1111/j.1540-6261.2004.00650.x

Venuti, E. K. (2004). The going-concern assumption revisited: Assessing a company's future viability. The CPA Journal (May).

Watts, R. L. (2003a). Conservatism in accounting Part I: Explanations and implications. Accounting Horizons, 17, 207-221. http://dx.doi.org/10.2308/acch.2003.17.3.207

Watts, R. L. (2003b). Conservatism in accounting Part II: Evidence and research opportunities. Accounting Horizons, 17, 287-301. http://dx.doi.org/10.2308/acch.2003.17.4.287

Watts, R. L., \& Zimmerman, J. (1986). Postive accounting theory. Englewood Cliffs, N.J.: Prentice-Hall Inc. 


\section{Notes}

Note 1. Roychowdhury and Watts (2007) attribute the negative relationship to growth and positive NPV as reflected in the beginning MB. Ball et al. (2010) econometrically demonstrate that changing market expectations about growth opportunities would generate that negative association. They cast the negative association as a property of income recognition in accounting interacting with properties of firms.

Note 2. An example of delayed accounting recognition of positive NPVs is that R \& D expenditures are immediately expensed but profit from $\mathrm{R} \& \mathrm{D}$ investments is not recognized until realized through sales transactions.

Another perspective (Ball et al., 2010; Givoly \& Hayn, 2000; Roychowdhury \& Watts, 2007) is that only a portion of MB (i.e., the difference between the net asset value and the book value of net assets) reflects unconditional conservatism; MB measures unconditional conservatism with an error related to growth and rents/monopoly.

Note 3. The legal regime change was a result of a 1994 major US Supreme Court decision in the Central Bank of Denver, N.A. v. First Interstate Bank of Denver case and the Private Securities Litigation Reform Act of 1995.

Note 4. Note that the mechanical explanations exert an enormous pressure on the power of the tests in our study to detect any meaningful effects of litigation. We may not observe any litigation effects unless 1) litigation generates a significant impact beyond that of growth and expectations about growth as well as the buffer effects, among others, and 2) the empirical settings provide sufficient power.

Note 5. One interesting observation is that "false alarm" eases in a less tight legal regime but it is accompanied by a far greater decrease in the probability of low signals in gloomy low-MB scenarios. It suggests that a relatively tight legal regime might make accounting reports more informative and enhance the social contractual efficiency of conservatism.

Note 6. Note that the expected litigation cost is much subdued for high-MB firms regardless of the legal regime. High-MB firms enjoy favorable stock performance and lower likelihood of earnings or asset overstatement, leaving investors with neither incentives nor legal bases to file lawsuits. The rather low expected litigation risk at the firm level virtually shields high-MB firms from the impact of a legal regime change.

Note 7. In response to perceived explosions of securities litigation in the early 1990s (Avery, 1996), the US Supreme Court acquitted the secondary defendant in Central Bank of Denver, N.A. v. First Interstate Bank of Denver on April 19, 1994. The ruling reversed a long history of court decisions and SEC enforcement actions where aiders and abettors were found liable under Rule 10b-5, making it more difficult for shareholders to sue auditors suspected of willfully aiding and abetting securities violations (Seligman, 1994). This resulted in a significant decrease in the legal liability exposure for auditors.

Note 8. Computers (SIC codes 3570-3577 and 7370-7374), electronics (SIC Codes 3600-3674), retailing (SIC codes 5200-5961) and pharmaceuticals/biotechnology (SIC codes 2833-2836 and 8731-8734).

We expect the differences in the level of litigiousness to be greater for $\mathrm{H} 1$ following the legal regime change compared with the cross-sectional difference in the level of litigiousness across industries for $\mathrm{H} 2$. Hence $\mathrm{H} 1$ tests have more power compared with $\mathrm{H} 2$ tests.

Note 9. The purpose of using annual returns ending three months after the fiscal year end is to ensure that the market response to previous year's earnings is excluded (Basu, 1997). We use net income (Compustat \#172) instead of income before extraordinary items (Compustat \#18) because the latter may not capture all the conservative accounting choices (Pope \& Walker, 1999). We repeat our analysis using Income before Extraordinary items and annual returns over the fiscal year. Results are similar.

Note 10 . We use a dummy variable LMB instead of continuous MB to allow for non-linearity in the relation between MB and AT. Ball et al. (2010) demonstrate that the relationship is non-linear.

Note 11. Because each firm contributes more than one observation, all $t$-statistics are based on cluster 
analysis at the firm level to correct for standard errors. Results remain intact with cluster analysis at the firmyear level.

The results from the expanded model show positive AT (i.e., the coefficients on D x R) for high-MB firms, confirming Gigler et al. (2009, p.791)'s concern about the "false alarm" harm of AT in increasing the probability of low signals when the future is bright as reflected in high MB. The greater AT for low-MB firms demonstrate the benefits of AT in increasing the probability of low signals when the future is gloomy as reflected in low MB. The increase in the probability of low signals when the future is gloomy (AT $=0.90$ for low-MB firms) far exceeds the "false alarm" increase in the probability of low signals when the future is bright ( $\mathrm{AT}=0.28$ for high-MB firms). It suggests that the false alarm noise introduced by conservatism when the future is bright is more than offset by the reduction in earnings inflation when the future is gloomy. The expanded model results show a significant decrease in AT for high-MB firms. It suggests that the "false alarm" eases in a less tight legal regime.

When we repeat the analysis using constant samples (i.e., firms that exist throughout the sample period and have all the required data items), results become weaker but still significant $(t=-2.00)$. In fact, $t$-statistics become smaller across the board when we use the constant samples both for the basic Basu model and the expanded model. Survivorship bias is a possible explanation. Non-surviving firms that went bankrupt or got delisted or acquired due to financial distress are likely to have faced higher probabilities of litigation and hence greater conservatism and stronger MB-AT association in a highly litigious environment.

Note 12. When we repeat the analysis using constant samples for $\mathrm{H} 2$, results also become much weaker as is the case of H1. Unfortunately, they are no longer significant ( $t=1.05$ for $\mathrm{H} 2 \mathrm{a} ; t=-0.57$ for $\mathrm{H} 2 \mathrm{~b}$ ) although they have the right signs. The weak $\mathrm{H} 2$ results are probably related to the survivorship bias as well as to the low power of the tests due to the smaller difference in the level of litigiousness across industries vs. the difference in the level of litigiousness following the legal regime change.

Note 13. We repeat our analysis using manufacturing (SIC 2000-4000), trade (SIC 5000-6000) and services (SIC 7000-9000), respectively. Results are similar using each of the three industries. We report the results using the manufacturing industry. The purpose of the industry level analysis is to address the measurement error concerns with the Basu model not to investigate whether the results are applicable to a particular industry. 